Original Research Paper

\title{
Assessment of Heavy Metals Migration in the Water - Soil - Fodder - Milk Food Chain in the Almaty Region
}

\author{
${ }^{1}$ Nurzhan Sarsembayeva, ${ }^{2 *}$ Tolkyn Abdigaliyeva, ${ }^{1}$ Zura Utepova, ${ }^{1}$ Asyl Biltebay and ${ }^{1}$ Aray Aidarbekova \\ ${ }^{1}$ Department of Veterinary Sanitary Examination and Hygiene, \\ Kazakh National Agrarian University, Almaty, Republic of Kazakhstan \\ ${ }^{2}$ Department of Food Biotechnology, Almaty Technological University, Almaty, Republic of Kazakhstan
}

\author{
Article history \\ Received: 25-03-2021 \\ Revised: 21-05-2021 \\ Accepted: 31-05-2021 \\ Corresponding Author: \\ Tolkyn Abdigaliyeva, \\ Department of Food \\ Biotechnology, Almaty \\ Technological University, \\ Almaty, Republic of Kazakhstan \\ Email: nurzhan_sarsembayeva@mail.ru
}

\begin{abstract}
This study presents the results of monitoring heavy metals $(\mathrm{Cd}, \mathrm{Pb}$, As and $\mathrm{Hg}$ ) in the water - soil - fodder - milk food chain. The research aimed to study the effect of lead, cadmium, mercury and arsenic in soil, water and components of the diet of cattle on their bioaccumulation in livestock products (milk) in basic farms of the Republic of Kazakhstan. The possibility of obtaining ecologically safe livestock products in meat and dairy cattle breeding has also been scientifically substantiated. A total of 120 soil samples, 60 water samples, 212 fodder samples and 60 milk samples were analyzed. Samples for the research were taken in spring, summer and fall in 2018 and 2019. Analysis of samples for the content of heavy metals was performed in the laboratory of the Kazakh-Japan Innovation Center at the Kazakh National Agrarian University. Determination of residual amounts of heavy metals (cadmium, lead, arsenic and mercury) was carried out on a novAA350 atomic absorption spectrometer (Analytik Jena, Germany) with a TaLab voltammetric analyzer. The obtained data allow concluding the degree of environmental pollution (water bodies, soil, agricultural fodder) and, consequently, the environmental safety of milk. Considering the data obtained, the authors have found that in the studied administrative districts of the Almaty region, the calculated transition coefficients in the water-soilfodder-milk system indicated that the largest transition of heavy metals was for lead and less migration was observed for mercury and arsenic. Fodders and feed additives preserved the tendency to accumulate trace elements. The analysis of heavy metals content in the study objects has shown that their distribution occurred in decreasing order: Lead $>$ zinc $>$ mercury $>$ arsenic.
\end{abstract}

Keywords: Breeding Products, Heavy Metals, Monitoring, Soil, Water

\section{Introduction}

Currently, strict quality requirements are imposed on the quality of food, raw materials and food products (Sarsembayeva et al., 2020). Heavy metals are the most dangerous to human health. They occupy a special place among other technogeneous pollutants since, not being subject to physicochemical or biological degradation, they get accumulated in the topsoil and change its properties, remain available for root absorption by plants for a long time and are actively involved in the processes of migration along the trophic chains (Fomina and Stepanova, 2015; Mansour, 2014; Gholizadeh et al., 2015). In the conditions of intensive development of the industry as a result of the activity of enterprises in the metallurgical, chemical, fuel-and-energy and processing industries, the concentration of heavy metals in the soil, the water and the air exceeds the permissible levels ten times (Verotchenko, 2014; Shahbazi et al., 2016). The initial links in this chain are the water and the soil, which accumulate pollutants in themselves, followed by plants (food and fodder crops), animals and crop and livestockbreeding production as the final link (Chary et al., 2008). Some salts of heavy metals, having traveled this long path, undergo significant changes at various technological stages of production and processing and the others (the most dangerous ones) enter the animal and human organisms, cause irreversible effects in various organs and tissues and contribute to various diseases (Nanda and Abraham, 2013). 
The highest level of air pollution is observed in the summer months. The proximity of forage land to industrial enterprises and highways results in the accumulation of heavy metals in the forage during the grazing period (Salah et al., 2013; Sherene, 2010; Rai et al., 2019). The daily intake of heavy metals with the forage and water results in their accumulation in the animal organism. With that, one part of them is localized in the organs and tissues and the other part is excreted from the organism, including milk and in this case, milk becomes dangerous for human consumption (Sarsembayeva et al., 2018; 2019). In this regard, the issue of monitoring the safety of dairy raw materials is urgent.

The specifics of the south of the Almaty region in agricultural production. In the region, many enterprises are engaged in the construction industry and engineering; it is also oversaturated with vehicles and requires constant sanitary and hygienic assessment of milk from the standpoint of lead, mercury, cadmium and arsenic. This will allow providing environmentally friendly types of dairy products for the population.

Modern society cannot exist without automobiles, which are the main type of transport and, of course, part of the everyday life of the population (Ahlam et al., 2017). It is known that one vehicle, on average, absorbs from the atmosphere more than four tons of oxygen every year, throwing out about $800 \mathrm{~kg}$ of carbon monoxide and $40 \mathrm{~kg}$ of nitric oxide with exhaust gases. One liter of gasoline contains about $1 \mathrm{~g}$ of lead tetraethyl, which is decomposed and released in the form of lead compounds. Vehicle operation leads to the formation of the photochemical smog, formed with the participation of dust, nitrogen oxides and solar ultraviolet rays. This creates new substances that exceed the initial substances in toxicity. The photochemical smog exacerbates pulmonary diseases among residents, including bronchial asthma (Szyczewski et al., 2009).

The existing problem of xenobiotic pollution of the water, the soil, the fodder and the livestock breeding products is significant for the farms in the Almaty region. The natural pastures and the Enbekshikazakh district land are located along the federal highway and are heavily exposed to pollutants.

Exhaust gases and soil vibrations from the vehicles lead to the degradation of the roadside vegetation and have adverse effects on all living system levels. The works on the distribution and accumulation of heavy metals in the environment in conditions of the Almaty region are insufficient.

Special information about the migration, accumulation and distribution of toxic elements along the food chain will help predict their content in plant and animal food raw materials, normalize their entry into the food chains to prevent contamination of the organisms of productive animals and obtain livestock breeding products that meet the sanitary and hygienic requirements, which determines the scientific and practical value of this work. In this regard, it is relevant to implement the measures for both the general detoxification of the animal organisms and how heavy metals transition into livestock breeding products and their accumulation.

The research aimed to study the dynamics related to the migration of residual amounts of heavy metals in the water - soil - fodder - milk food chain, planning the scientifically substantiated measures for improving the quality and the veterinary-and-sanitary assessment of the livestock breeding products safety.

\section{Materials and Methods}

\section{The Objects of the Studies}

The studies were performed at KazAgroStandard LLP and the Aidarbayev peasant farm in the Almaty region. The laboratory of the Kazakh-Japan Innovation Center of the Kazakh National Agrarian University.

The amounts of heavy metals were found in the environment (the water, the soil and the fodder) and animal breeding (milk in this case). A total of 120 soil samples, 60 water samples, 212 fodder samples and 60 milk samples were analyzed. The samples had been taken in the spring, summer and autumn in 2018 and 2019.

\section{The Water}

The water samples were taken according to the following method: The samples were taken from the drinking bowl at the barn entrance and at 2-3 various barn locations. The samples were taken in sterile conditions. The vials were signed and stored in a cool and dark place during transportation (Rosstandart, 2012). They were delivered to the laboratory the next day.

\section{The Soil}

Samples were taken from the upper humus horizon to the depth of the arable layer $(0-30 \mathrm{~cm})$ following the soil science methods (Gosstandart of the USSR, 1989) for determining the content of heavy metals in the soil. The soil samples were taken three times a year: In the spring after snow melting, in the summer and the autumn - during harvesting. The weight of each sample was $400 \mathrm{~g}$. The concentration of heavy metals was determined using the following method (M-MVI-80-2008, 2008) a weighed sample portion of $2.0 \mathrm{~g}$ was placed in a glass beaker, 10 $\mathrm{cm}^{3}$ of nitric acid with a molar concentration of 0.5 $\mathrm{mol} / \mathrm{dm}^{3}$ was added to it; the sample was stirred and kept at a temperature of $90^{\circ} \mathrm{C}$; stirring continued for $3 \mathrm{~h}$. Then the sample was filtered through a paper filter into a 100 $\mathrm{cm}^{3}$ volumetric flask. The volume was brought to the mark with bidistilled water. The resulting solution was analyzed with Atomic Absorption Spectrometry (AAS). The mass fraction of the determining element in the 
sample for each determination $\left(X^{A A S} i\right)$, ppm, was calculated by Eq. (1):

$X_{i}^{A A S}=\frac{\left(C_{M i}-C_{X}\right) \cdot V \cdot k}{m}$,

Where:

$C_{M i}=$ The mass concentration of an element in the analyzed solution, found from the calibration characteristic, $\mathrm{mg} / \mathrm{dm}^{3}$

$C_{X}=$ The mass concentration of an element in a blank solution, found from the calibration characteristic, $\mathrm{mg} / \mathrm{dm}^{3}$

$V=$ The volume of the analyzed solution $\left(\mathrm{F}=100 \mathrm{~cm}^{3}\right)$

$k=$ The dilution factor (from 1 to 1,000 )

$t \quad=$ The weight of the sample, $\mathrm{g}$

\section{The Diet}

The fodders procured directly at the agricultural enterprises and forming the base of the diet were analyzed. The green fodder was presented by perennial and annual herbs (Swedish clover, blue hybrid alfalfa, yellow and white melilot and peas-and-oats mixes). Soybean meal and distillery stillage were studied as feed additives. Silage consisted of corn and sunflower. The concentrated fodder included chopped barley grain, wheat and corn. The herbs from the pastures were sampled every month from June to September from 10 accounting plots with one square meter area diagonally on the plot. The herbs were mowed at the height of $3-5 \mathrm{~cm}$. The fodder samples were taken according to the following method: Point samples were taken with barn probe from the fodder that was stored in warehouses. The entire surface of mixed fodder was divided into squares with an area of 4-5 $\mathrm{m}^{2}$ each. Samples were taken in the middle of each square (from the upper and lower layers with the height of the fodder bulk up to $0.75 \mathrm{~m}$; and from the upper, middle and lower layers with the height of the fodder bulk over $0.75 \mathrm{~m}$ ). The mixed fodder, which was in closed bags, was sampled with a bag sampling probe from the upper lower part. The probe was inserted with the groove downward, then rotated $180^{\circ}$ and pulled out. The number of bags from which samples were taken accounted for $5 \%$ of all batches (Rosstandart, 2016).

The raw materials were dried immediately after harvesting by air drying to avoid the destruction of substances and remove moisture. The storage and harvesting conditions were the same for all plants. The content of heavy metals was determined by the atomic absorption method (Gosstandart of Russia, 2001): A test sample weighing 10-20 g was placed in the crucible. The crucible was then placed in a cold muffle furnace and the temperature was increased to $250-300^{\circ} \mathrm{C}$ and cooled. The ash was moistened with a few drops of distilled water, 5 $\mathrm{cm}^{3}$ of hydrochloric acid solution diluted with distilled water in a 1:1 ratio was added. The crucible was then placed in a boiling water bath or electric hot plate and evaporated to a wet state, avoiding splashing and calcination of the precipitate. $10-15 \mathrm{~cm}^{3}$ of nitric acid solution diluted with distilled water in a 1:1 ratio was poured into the crucible with a dispenser. The crucible was covered with a watch glass and heated on an electric stove to boiling or kept in a boiling water bath for $30 \mathrm{~min}$. After cooling, the ash solution was filtered into a volumetric flask with a capacity of $50 \mathrm{~cm}^{3}$ through a paper filter. The filter was thoroughly rinsed with a nitric acid solution diluted with distilled water in a 1:1 ratio. The crucible was rinsed several times with hot distilled water and poured onto a filter. The filter was thoroughly washed with distilled water, the volume of the solution in the flask was brought up to the mark with distilled water and mixed. The sediment was allowed to settle. The liquid above the sediment was carefully removed for analysis. The determination of the mass concentration of metals in the ash solution was carried out according to the following analytical lines, nm: Lead - 217.0; cadmium - 228.8. The mass fraction of metal in the test sample $(\mathrm{mg} / \mathrm{kg})$ was calculated by Eq. (2):

$X=\frac{V\left(c_{1}-c_{0}\right)}{m}$,

Where:

$c_{1}=$ The mass concentration of metal in ash solution, found according to the calibration graph, $\mathrm{mg} / \mathrm{dm}^{3}$

$c_{0}=$ The mass concentration of metal in the solution of the control experiment, $\mathrm{mg} / \mathrm{dm}^{3}$

$V=$ The volume of the initial ash solution, $\mathrm{cm}^{3}$

$m$ = The weight of the sample, $\mathrm{g}$

\section{The milk}

Samples of the milk from flasks or tanks were taken using the following method: A clean and dry tube was immersed into the milk at the rate that allowed the milk to enter it simultaneously immersion. After that, tightly closing the top hole with a thumb, the tube was quickly removed and the milk was poured into a clean, dry vial with a rubber stopper. Labels with appropriate inscriptions were glued onto the vials with the milk samples and the vials were stored in a refrigerator until the next day (Rosstandart, 2014).

\section{Measuring Instruments and Analysis}

The content of heavy metals (cadmium, lead, arsenic and mercury) was quantitatively determined on a novAA350 atomic absorption spectrometer (Analytik Jena, Germany) with a TaLab voltammetric analyzer. Sample preparation of soil, water, fodder and milk samples was carried out using dry and acid mineralization: The weighed portion of the soil and fodder was placed on an electric stove and charred carefully, avoiding strong smoke. After the cessation of smoke emission, the bowl was placed in an electric furnace 
previously heated to the temperature of about $250^{\circ} \mathrm{C}$. Nitric acid solution was added to a weighed amount of water and milk at the rate of $1 \mathrm{~cm}^{3}$ per $50 \mathrm{~g}$ of the product, mixed, placed on an electric stove and carefully charred until the smoke emission ceased. The bowl was placed in an electric furnace previously heated to a temperature of about $250^{\circ} \mathrm{C}$. After the end of charring, the mineralization of the samples was carried out in an electric furnace with a gradual increase of the temperature to $450^{\circ} \mathrm{C}$. Mineralization was continued at this temperature until gray ash was obtained. The bowl with ash was then removed from the electric furnace after 10$15 \mathrm{~h}$ of ashing, cooled to room temperature and the contents were moistened dropwise with the minimum amount of nitric acid solution. The acid was evaporated to dryness in a water bath, followed by holding in an oven at temperatures up to $140^{\circ} \mathrm{C}$. After cooling, the weighed bowl was again placed in a cooled electric furnace. The temperature was gradually brought to $300^{\circ} \mathrm{C}$ and kept for $0.5 \mathrm{~h}$. This cycle was repeated several times (Gosstandart of Russia, 1995).

Laboratory tests for determining the content of the salts of heavy metals and toxic elements in the objects were performed following the national standard of the Republic of Kazakhstan ST RK ISO 8288-2005 Determination of the Content of Cobalt, Nickel, Copper, Zinc, Cadmium and Lead. Flame Atomic Absorption Spectrometric Methods, MU 08-47/162 Voltammetric Method for Measuring the Mass Concentration of Mercury and MU 31-09/04 Method for Measuring Mass Concentration of Arsenic by Inversion Voltammetry on TA Analyzers.

While calculating the concentrations of the determining elements in the samples, the results were metrologically processed as follows (Gosstandart of
Russia, 2002): Under the conditions of repeatability, two groups of measurements were performed: The first group, which gave $n_{1}$ measurement results with the $\bar{y}_{1}$ arithmetic mean and the second group, which gave $n_{2}$ measurement results with the $\bar{y}_{2}$ arithmetic mean; and the standard deviation of the difference $\left(\bar{y}_{1}-\bar{y}_{2}\right)$ was calculated by Eq. 3:

$$
\sigma=\sqrt{\sigma_{r}^{2}\left(\frac{1}{n_{1}}+\frac{1}{n_{2}}\right)},
$$
Eq. 4:

The critical difference for $\left(\bar{y}_{1}-\bar{y}_{2}\right)$ was calculated as

$$
C D=2.8 \sigma_{r} \sqrt{\frac{1}{2 n_{1}}+\frac{1}{2 n_{2}}},
$$

where the probability level was $95 \%$.

Quantitative indicators of the results of the studies were processed within a variational-statistical analysis using the Microsoft Excel (2003), Statgraf and Statgraf Plus software suites. The veracity of differences was determined using the Student-Fisher method.

\section{Results and Discussion}

\section{The Water}

The content of toxic elements $(\mathrm{Cd}, \mathrm{Hg}, \mathrm{Pb}$ and $\mathrm{As})$ in the water was studied in the spring, summer and autumn in 2018 at the base farms in the Almaty region (KazAgroStandard LLP and the Aidarbayev peasant farm).

\begin{tabular}{|c|c|c|c|c|c|}
\hline Farm & $\begin{array}{l}\text { Sample name } \\
\text { MPC }(\mathrm{mg} / \mathrm{kg})\end{array}$ & $\begin{array}{l}\mathrm{Cd} \\
0,001 \\
\end{array}$ & $\begin{array}{l}\mathrm{Pb} \\
0.03 \\
\end{array}$ & $\begin{array}{l}\text { As } \\
0.05\end{array}$ & $\begin{array}{l}\mathrm{Hg} \\
0.0005 \\
\end{array}$ \\
\hline \multirow[t]{12}{*}{ Aidarbayev peasant farm } & $\mathrm{A} / 1-2-1$ & 0.0006 & 0.0213 & 0 & 0 \\
\hline & $\mathrm{A} / 1-2-2$ & 0.0003 & 0.0176 & 0 & 0 \\
\hline & $\mathrm{A} / 1-2-3$ & 0.0008 & 0.0250 & 0 & 0 \\
\hline & $\mathrm{A} / 1-2-4$ & 0.0003 & 0.0236 & 0 & 0 \\
\hline & $\mathrm{A} / 1-2-5$ & 0.0005 & 0.0119 & 0 & 0 \\
\hline & A/1-2-6 & 0.0004 & 0.0233 & 0 & 0 \\
\hline & $\mathrm{A} / 1-2-7$ & 0.0005 & 0.0233 & 0 & 0 \\
\hline & $\mathrm{A} / 1-2-8$ & 0.0004 & 0.0178 & 0 & 0 \\
\hline & $\mathrm{A} / 1-2-9$ & 0.0005 & 0.0163 & 0 & 0 \\
\hline & $\mathrm{A} / 1-2-10$ & 0.0005 & 0.0186 & 0 & 0 \\
\hline & $\mathrm{A} / 1-2-11$ & 0.0005 & 0.0240 & 0 & 0 \\
\hline & $\mathrm{A} / 1-2-12$ & 0.0005 & 0.0170 & 0 & 0 \\
\hline \multirow[t]{8}{*}{ KazAgroStandard LLP } & $\mathrm{K} /-2-1$ & 0.0007 & 0.0126 & 0 & 0 \\
\hline & $\mathrm{K} /-2-2$ & 0.0005 & 0.0191 & 0 & 0 \\
\hline & $\mathrm{K} /-2-3$ & 0.0005 & 0.0131 & 0 & 0 \\
\hline & $\mathrm{K} /-2-4$ & 0.0003 & 0.0178 & 0 & 0 \\
\hline & $\mathrm{K} /-2-5$ & 0.0003 & 0.0165 & 0 & 0 \\
\hline & $\mathrm{K} /-2-6$ & 0.0005 & 0.0171 & 0 & 0 \\
\hline & $\mathrm{K} /-2-7$ & 0.0006 & 0.0184 & 0 & 0 \\
\hline & $\mathrm{K} /-2-8$ & 0.0003 & 0.0174 & 0 & 0 \\
\hline
\end{tabular}

Table 1: The average content of heavy metals and toxic elements in the water at the base farms in $2018, \mathrm{mg} / \mathrm{kg}(\mathrm{M} \pm \mathrm{g})$

Note: A/-2-(1-12)-water samples from the Aidarbayev peasant farm; K/-2-(1-8)-water samples from KazAgroStandard LLP 
The cadmium content in the water from the Aidarbayev peasant farm, on average, amounted to 0.0005 $\mathrm{mg} / \mathrm{kg}$. In the water from KazAgroStandard LLP, the content was $0.0004 \mathrm{mg} / \mathrm{kg}$ (Table 1).

The concentration of lead in the water from KazAgroStandard LLP was, on average $0.0156 \mathrm{mg} / \mathrm{kg}$. The water from the Aidarbayev farm - $0.0198 \mathrm{mg} / \mathrm{kg}$ did not exceed the maximum permissible concentration of lead in the water. No concentration of mercury and arsenic was found in the water from KazAgroStandard LLP and the Aidarbayev peasant farm. The results showed that the concentration of lead and cadmium in the water from the base farms in the Almaty region did not exceed the MPC.

\section{The Soil}

If contaminated with heavy metals, the soil becomes poor in nutrients (White et al., 2006). The soil samples studies showed that the content of lead, cadmium, mercury and arsenic in the soil cover at the base farms in the Almaty region did not exceed the permissible concentrations for the studied parameters.

Table 2: The average content of toxic elements in the soil cover at the base farms, $\mathrm{mg} / \mathrm{kg}(\mathrm{M} \pm \mathrm{g})$

\begin{tabular}{|c|c|c|c|c|c|}
\hline Farm & $\begin{array}{l}\text { Sample name } \\
\text { MPC (mg/kg) }\end{array}$ & $\begin{array}{l}C d \\
1.0 \\
\end{array}$ & $\begin{array}{l}P b \\
3.2 \\
\end{array}$ & $\begin{array}{l}A s \\
2.0 \\
\end{array}$ & $\begin{array}{l}\mathrm{Hg} \\
2.1 \\
\end{array}$ \\
\hline \multicolumn{6}{|l|}{2018} \\
\hline \multirow[t]{13}{*}{ Aidarbayev peasant farm } & $\mathrm{A} / 1-1-1$ & 0.0229 & 0.2501 & 0.2652 & 0.4124 \\
\hline & $\mathrm{A} / 1-1-2$ & 0.0235 & 0.2953 & 0.3419 & 0.3986 \\
\hline & $\mathrm{A} / 1-1-3$ & 0.0264 & 0.2888 & 0.5214 & 0.4875 \\
\hline & $\mathrm{A} / 1-1-4$ & 0.0267 & 0.2145 & 0.3518 & 0.4365 \\
\hline & $\mathrm{A} / 1-1-5$ & 0.0298 & 0.2654 & 0.2722 & 0.4235 \\
\hline & $\mathrm{A} / 1-1-6$ & 0.0295 & 0.2685 & 0.2785 & 0.4251 \\
\hline & $\mathrm{A} / 1-1-7$ & 0.0296 & 0.2532 & 0.2752 & 0.4521 \\
\hline & $\mathrm{A} / 1-1-8$ & 0.0296 & 0.2641 & 0.2452 & 0.4351 \\
\hline & $\mathrm{A} / 1-1-9$ & 0.0263 & 0.2541 & 0.2752 & 0.4185 \\
\hline & $\mathrm{A} / 1-1-10$ & 0.0289 & 0.2687 & 0.2412 & 0.4023 \\
\hline & $\mathrm{A} / 1-1-11$ & 0.0296 & 0.2896 & 0.3420 & 0.3985 \\
\hline & $\mathrm{A} / 1-1-12$ & 0.0263 & 0.2478 & 0.3485 & 0.3987 \\
\hline & Average amount & 0.0274 & 0.2633 & 0.3132 & 0.4241 \\
\hline \multirow{9}{*}{ KazAgroStandard LLP } & $\mathrm{K} / 1-1-1$ & 0.0224 & 0.2814 & 0.1643 & 0.2128 \\
\hline & $\mathrm{K} / 1-1-2$ & 0.0244 & 0.2580 & 0.3258 & 0.9561 \\
\hline & $\mathrm{K} / 1-1-3$ & 0 & 0.0228 & 0.2818 & 0.1687 \\
\hline & $\mathrm{K} / 1-1-4$ & 0.2201 & 0.0254 & 0.2596 & 0.3294 \\
\hline & $\mathrm{K} / 1-1-5$ & 0 & 0.0321 & 0.2922 & 0.1734 \\
\hline & $\mathrm{K} / 1-1-6$ & 0.0218 & 0.2636 & 0.1581 & 0.0214 \\
\hline & $\mathrm{K} / 1-1-7$ & 0 & 0.2985 & 0.1744 & 0.2214 \\
\hline & $\mathrm{K} / 1-1-8$ & 0.0352 & 0.2981 & 0.1521 & 0.1985 \\
\hline & Average amount & 0.0405 & 0.1850 & 0.2260 & 0.2852 \\
\hline \multicolumn{6}{|l|}{2019} \\
\hline \multirow[t]{13}{*}{ Aidarbayev peasant farm } & $\mathrm{A} / 2-1-1$ & 0.3698 & 0.3541 & 0.3896 & 0.5154 \\
\hline & $\mathrm{A} / 2-1-2$ & 0.3685 & 0.3587 & 0.3874 & 0.5423 \\
\hline & $\mathrm{A} / 2-1-3$ & 0.3698 & 0.3485 & 0.3785 & 0.5478 \\
\hline & $\mathrm{A} / 2-1-4$ & 0.3686 & 0.3556 & 0.3896 & 0.5174 \\
\hline & $\mathrm{A} / 2-1-5$ & 0.3656 & 0.3558 & 0.3874 & 0.5458 \\
\hline & $\mathrm{A} / 2-1-6$ & 0.3647 & 0.3452 & 0.3736 & 0.5414 \\
\hline & $\mathrm{A} / 2-1-7$ & 0.3678 & 0.3557 & 0.3885 & 0.5163 \\
\hline & $\mathrm{A} / 2-1-8$ & 0.3645 & 0.3589 & 0.3854 & 0.5478 \\
\hline & $\mathrm{A} / 2-1-9$ & 0.3663 & 0.3475 & 0.3745 & 0.5485 \\
\hline & $\mathrm{A} / 2-1-10$ & 0.3663 & 0.3578 & 0.3842 & 0.5196 \\
\hline & $\mathrm{A} / 2-1-11$ & 0.3615 & 0.3589 & 0.3832 & 0.5452 \\
\hline & $\mathrm{A} / 2-1-12$ & 0.3698 & 0.3442 & 0.3796 & 0.5411 \\
\hline & Average amount & 0.3669 & 0.3534 & 0.3835 & 0.5357 \\
\hline \multirow[t]{9}{*}{ KazAgroStandard LLP } & $\mathrm{K} / 1-1-1$ & 0.0325 & 0.2715 & 0.1844 & 0.2324 \\
\hline & $\mathrm{K} / 1-1-2$ & 0.0248 & 0.2585 & 0.3258 & 0.9565 \\
\hline & $\mathrm{K} / 1-1-3$ & 0 & 0.0287 & 0.2885 & 0.1785 \\
\hline & $\mathrm{K} / 1-1-4$ & 0.2785 & 0.1258 & 0.2698 & 0.4871 \\
\hline & $\mathrm{K} / 1-1-5$ & 0 & 0.0326 & 0.2978 & 0.1796 \\
\hline & $\mathrm{K} / 1-1-6$ & 0.0219 & 0.2641 & 0.1589 & 0.0225 \\
\hline & $\mathrm{K} / 1-1-7$ & 0 & 0.2974 & 0.1786 & 0.2217 \\
\hline & $\mathrm{K} / 1-1-8$ & 0.0386 & 0.2978 & 0.1586 & 0.1947 \\
\hline & Average amount & 0.0495 & 0.1975 & 0.2328 & 0.3091 \\
\hline
\end{tabular}


According to the studies results, the content of cadmium in the soil at Kaz Agro Standard LLP in 2018, on average, amounted to $0.0405 \mathrm{mg} / \mathrm{kg}$ and that at the Aidarbayev peasant farm amounted to $0.0274 \mathrm{mg} / \mathrm{kg}$ (Table 2). In 2019, their contents were 0.0495 and $0.3669 \mathrm{mg} / \mathrm{kg}$, respectively. The concentration of lead in the soil cover at KazAgroStandard LLP over the two years averaged to $0.1912 \mathrm{mg} / \mathrm{kg}$, which did not exceed the maximum permissible concentration for cadmium in the soil. The twoyear value of lead content in the soil cover at the Aidarbayev peasant farm averaged to $0.3083 \mathrm{mg} / \mathrm{kg}$.

As the results of the show, the content of lead and cadmium in the soil at the Aidarbayev peasant farm exceeded the same at KazAgroStandard LLP, which could be attributed to the more lowland location of the farm.

The concentration of mercury in the soil samples from KazAgroStandard LLP during the study averaged 0.2971 $\mathrm{mg} / \mathrm{kg}$, while in the soil from the Aidarbayev peasant farm, the average mercury level was $0.4799 \mathrm{mg} / \mathrm{kg}$. The obtained results showed that mercury concentration in the soil at the base farms did not exceed the MPC. In most cases, arsenic transfer from the soil to the plant was insignificant (Hapke, 1996). Studying the content of arsenic at the tested farms did not exceed the standard values either.

Thus, the lead, cadmium, mercury and arsenic content in the soil samples from the Aidarbayev peasant farm and KazAgroStandard LLP, located in the Almaty region, did not exceed the maximum permissible concentration.

The studies showed that the predominantly natural origin elements were fairly evenly distributed across various soil and climatic zones of the region. With that, lead and cadmium were more actively accumulated in the arable layer.

\section{The Diet}

Plants are the second important factor (after the soil) to transfer heavy metals to the human organism (Skalny and Bykov, 2003). As the studies showed, the heavy metals in the fodder samples, the feed additives and the herbs in the grazing period were different at various farms and varied during the studies (Table 3).

The average cadmium content at the studied farms ranged from 0.3 to $0.7 \mathrm{mg} / \mathrm{kg}$. In the fodder samples from the Aidarbayev peasant farm, the content of cadmium over the two years of harvesting was the lowest $(0.0332$ $\mathrm{mg} / \mathrm{kg}$ ) compared to KazAgroStandard LLP. However, the content of lead increased compared to KazAgroStandard LLP.

A more than 1.5 times increase in the lead in the fodder for cattle was noted at the Aidarbayev peasant farm, compared to the other farm. An increase in the lead content by $13 \%$ was also noted during the grazing period from March to September at KazAgroStandard LLP. The content of cadmium in the fodder at the Aidarbayev peasant farm remained low throughout the studies. A sharp increase in the content of arsenic was observed in the cattle fodder samples at KazAgroStandard LLP. The average amount was $0.0809 \mathrm{mg} / \mathrm{kg}$. However, this value did not exceed the MPC. Also, the accumulation of mercury over the two years proceeded faster at KazAgroStandard LLP farm. The average mercury content in the samples from these farms was 0.0104 and $0.0037 \mathrm{mg} / \mathrm{kg}$, respectively. The average content of heavy metals and toxic elements in the cattle fodder is shown in Table 3. Attention should be paid to the fact that the content of metals in the diets of the cows at all studied farms did not exceed the MPC.

Table 3: The average content of heavy metals and toxic elements in the cattle diets at the farms in the Almaty region in $2018-2019$

\begin{tabular}{|c|c|c|c|c|c|c|}
\hline \multirow[b]{2}{*}{ Farm } & \multirow[b]{2}{*}{ Year } & \multicolumn{5}{|c|}{ Salts of heavy metals $(\mathrm{mg} / \mathrm{kg})$} \\
\hline & & $\begin{array}{l}\text { Months and the } \\
\text { number of samples }\end{array}$ & $\begin{array}{l}\text { Cadmium } \\
(\mathrm{MPC}=0.3)\end{array}$ & $\begin{array}{l}\text { Lead } \\
(\mathrm{MPC}=3.2)\end{array}$ & $\begin{array}{l}\text { Arsenic } \\
(\mathrm{MPC}=0.5)\end{array}$ & $\begin{array}{l}\text { Mercury } \\
(\mathrm{MPC}=0.05)\end{array}$ \\
\hline \multirow[t]{7}{*}{ Aidarbayev peasant farm } & 2018 & March (32 samples) & 0.0336 & 0.8018 & 0.0035 & 0.0005 \\
\hline & & June (32 samples) & 0.0452 & 1.231 & 0.0125 & 0.0052 \\
\hline & & September (32 samples) & 0.0821 & 0.985 & 0.0052 & 0.0125 \\
\hline & 2019 & March (33 samples) & 0 & 0 & 0.0014 & 0.0046 \\
\hline & & June (48 samples) & 0 & 0.0596 & 0.0004 & 0 \\
\hline & & September (35 samples) & 0.0385 & 0.0079 & 0 & 0 \\
\hline & Average amount & 0.0332 & 0.5142 & 0.0038 & 0.0037 & \\
\hline \multirow[t]{7}{*}{ KazAgroStandard LLP } & 2018 & March (20 samples) & 0.0938 & 0.4758 & 0.1939 & 0.0118 \\
\hline & & June (20 samples) & 0.1232 & 0.5325 & 0.2658 & 0.0254 \\
\hline & & September (20 samples) & 0.1325 & 0.9523 & 0.0254 & 0.0254 \\
\hline & 2019 & March (72 samples) & 0.0004 & 0.0086 & 0 & 0 \\
\hline & & June (56 samples) & 0 & 0.0294 & 0 & 0 \\
\hline & & September (42 samples) & 0.0795 & 0.0239 & 0 & 0 \\
\hline & Average amount & 0.0715 & 0.3371 & 0.0809 & 0.0104 & \\
\hline
\end{tabular}


Thus, the studies showed that the content of heavy metals and toxic elements such as lead, cadmium, arsenic and mercury in the fodder and feed additives in the diet of the cows at KazAgroStandard LLP and the Aidarbayev peasant farm located in the Almaty region did not exceed the MPC. However, the accumulation of metals in the pasture herbs by the end of plant vegetation was noted. Besides, it was found that at KazAgroStandard LLP and the Aidarbayev peasant farm, the content of lead and cadmium in the pasture herbs had increased by the end of the vegetation season. Therefore, it is necessary to monitor the content of lead and cadmium in the pasture herbs at these farms. The authors also consider it necessary to perform studies for identifying the types of heavy metal (primarily, lead) concentrators and their further replacement with other economically valuable species that do not accumulate metals in hazardous concentrations.

\section{The Milk}

Monitoring the content of heavy metals in the environmental objects during the 24 months of the study at the base farms in the Almaty region revealed heavy metals in the milk samples. The milk contained heavy metals $(\mathrm{Cd}, \mathrm{Pb})$ in various shares, while mercury and arsenic were not found. The largest amounts of $\mathrm{Cd}$ and $\mathrm{Pb}$ in the milk of the cows at the Aidarbayev peasant farm were found in the autumn (Table 4). They amounted to 0.0101 and $0.0075 \mathrm{mg} / \mathrm{kg}$. Simultaneously, the amount of these heavy metals in the milk from the cows at KazAgroStandart LLC was 0.0063 and $0.0038 \mathrm{mg} / \mathrm{kg}$ (Table 4). However, the above values did not exceed the MPC.

The calculation of the content of heavy metals in the cow milk showed that an increase in the concentration of cadmium and lead in the cow milk in the winter stall period and the summer pasture periods was accompanied by an increase in their content in the fodder and depended on the soil-and-climatic conditions of the base farms in the Almaty region.

Cadmium had the highest migration coefficient to milk from the fodder, especially in the winter stall period. In the summer pasture period, these coefficients were 2-3 times lower than in the stall period in the studied soil-and-climatic zones of the Almaty region. However, this difference was less veracious here (only 0.5-1 times). Lead is mainly transferred to the cow milk from the nonpreserved fodder (from diets of the summer grazing period). Here, the coefficients are 1-2 times higher than those of the winter stall period of cows keeping. The technology of harvesting the fodder has less effect on mercury and arsenic migration from the diet to the product. The migration of the diet elements to the milk was influenced not only by the different technology of their harvesting but also by the agroclimatic conditions of fodder growing.

The mechanism of the toxic effect of this element is explained by its ability to block sulfhydryl groups in the molecule of enzymes involved in the synthesis of porphyrins (Gabryszuk et al., 2010). The residual amounts of heavy metals in this study can be associated with animal fodder and water contamination. Such contaminants can be released into milk at various levels. They can also enter milk and products through processing procedures. Such studies have been studied in the work of Tripathi et al. (1999). According to the results of Gabryszuk's work (Gabryszuk et al., 2010), the Pb concentration in the milk of cows from organic farms was significantly higher and ranged from 0.0041 to $0.0062 \mu \mathrm{g} / \mathrm{ml}$.

Table 4: The content of heavy metals in the samples of cow milk from the Aidarbayev peasant farm and KazAgroStandard LLP

\begin{tabular}{|c|c|c|c|c|c|}
\hline \multirow[b]{2}{*}{ Year } & \multirow[b]{2}{*}{$\begin{array}{l}\text { Sampling period } \\
\text { MPC }\end{array}$} & \multicolumn{4}{|c|}{ The amounts of heavy metals, $\mathrm{mg} / \mathrm{kg}$} \\
\hline & & $\begin{array}{l}\mathrm{Cd} \\
0.03\end{array}$ & $\begin{array}{l}\mathrm{Pb} \\
0.1\end{array}$ & $\begin{array}{l}\text { As } \\
0.1\end{array}$ & $\begin{array}{l}\mathrm{Hg} \\
0.05\end{array}$ \\
\hline \multirow[t]{9}{*}{2018} & Aidarbayev peasant farm & & & & \\
\hline & Spring & 0.0078 & 0.0033 & 0 & 0 \\
\hline & Summer & 0.0079 & 0.0038 & 0 & 0 \\
\hline & Autumn & 0.0101 & 0.0075 & 0 & 0 \\
\hline & KazAgroStandard LLP & & & & \\
\hline & & $\mathrm{Cd}$ & $\mathrm{Pb}$ & As & $\mathrm{Hg}$ \\
\hline & Spring & 0.0087 & 0.0014 & 0 & 0 \\
\hline & Summer & 0.0072 & 0.0017 & 0 & 0 \\
\hline & Autumn & 0.0063 & 0.0038 & 0 & 0 \\
\hline \multirow[t]{8}{*}{2019} & Aidarbayev peasant farm & & & & \\
\hline & Spring & 0.0095 & 0.0095 & 0 & 0 \\
\hline & Summer & 0.0152 & 0.0152 & 0 & 0 \\
\hline & Autumn & 0.0106 & 0.0145 & 0 & 0 \\
\hline & KazAgroStandard LLP & & & & \\
\hline & Spring & 0.0063 & 0.0045 & 0 & 0 \\
\hline & Summer & 0.0174 & 0.0052 & 0 & 0 \\
\hline & Autumn & 0.0123 & 0.0032 & 0 & 0 \\
\hline
\end{tabular}


The migration of lead to the cow milk was the least from the diets of KazAgroStandard LLP. It was only 1.2 times higher in the summer period, compared to the winter period. The migration was high from the Aidarbayev peasant farm diets (2.3 times higher than from the winter diet). The lowest coefficients of heavy metals migration into the cow milk from the diets of the winter stall period were noted at KazAgroStandard LLP. For mercury and arsenic, the picture was exactly the opposite: The migration rates were lower from the diets at the Aidarbayev peasant farm and higher from KazAgroStandard LLP diets.

Lante et al. (2006) stated that the accumulation of heavy and toxic metals in milk and dairy products might vary by location and district. In this regard, several studies have been carried out to assess the content of metals in milk from different regions.

\section{Migration of Heavy Metals and Toxic Elements in the Food - Water - Soil - Fodder - Milk Chain}

Analyzing the diet of the cows in the districts of the Almaty region, it should be noted that the highest content of heavy metals in the fodder mass was noted for lead. This element concentration at the Enbekshikazakh and Zhambul regions had the maximum values and amounted to 0.51 and $0.33 \mathrm{mg} / \mathrm{kg}$, respectively, the MPC being 3.2 $\mathrm{mg} / \mathrm{kg}$. The content of arsenic in the soil ranged from 0.35 to $0.23 \mathrm{mg} / \mathrm{kg}$ with the MPC of $2.0 \mathrm{mg} / \mathrm{kg}$; that of cadmium - from 0.05 to $0.20 \mathrm{mg} / \mathrm{kg}$ with the MPC of 1.0 $\mathrm{mg} / \mathrm{kg}$; and that of mercury - from 0.30 to $0.48 \mathrm{mg} / \mathrm{kg}$ with the MPC of $2.1 \mathrm{mg} / \mathrm{kg}$, which corresponded to the sanitary standards (Table 5). The soil $\mathrm{pH}$ had a significant effect on the mobility of metals. In the soil with an acidic reaction of the medium, the mobility of heavy metals increased, such soil being characteristic of the Enbekshikazakh district.

The results of analyzing the fodder samples in the districts of the Almaty region show that the highest concentration of lead was noted at the Aidarbayev peasant farm $(0.5142 \mathrm{mg} / \mathrm{kg})$ and the minimum concentration of lead was noted at KazAgroStandard LLP $(0.3371 \mathrm{mg} / \mathrm{kg})$ with the MPC of $3.2 \mathrm{mg} / \mathrm{kg}$. The arsenic and cadmium content was insignificant compared to the MPC; the highest mercury concentration was noted in the fodder at KazAgroStandard LLP $(0.0104 \mathrm{mg} / \mathrm{kg})$, which was 4.8 times lower than the MPC.

In general, the pollution of the water, the soil and the fodder in the diet of lactating cows during the grazing period did not exceed the adopted norms. In the works of Grigorieva and Mironova (2018), it was noted that the content of heavy metals was higher both in the soil and in the above-ground parts of the.

The constant intake of high concentrations of heavy metals with the fodder may accumulate in the organs and tissues of animals and the milk. In this regard, the authors studied the content of these elements in the milk in several Almaty region districts during the grazing period; the values are shown in Table 5.

Caggiano et al. (2005) studies showed that the content of heavy metals and toxic elements in the milk and dairy products depended on such factors as production peculiarities and possible contamination of equipment during production, packaging and storage. In the milk samples obtained in the territories of the Aidarbayev peasant farm and KazAgroStandard LLP, no facts of heavy metal content exceeding the hygienic norms were noted. Milk and dairy products usually contain a very low $\mathrm{Cd}$ concentration, except for the animals that consume contaminated fodder and water (Abdulkhaliq et al., 2012). However, given the ability of heavy metals to accumulate in the organism, the patterns of their accumulation and joint effects on human health require studying. Thus, knowing the ecological state of the water, the soil and the fodder, taking into account the antagonistic properties of pairs of toxicants, it is possible to balance the diets for eliminating the most toxic antagonist (Fig. 1 and 2). Some sources state that the concentrations of heavy metals and toxic elements depend on the season. For example, in the studies of Kazhmukhanbetkizi et al. (2019), it was proven that the content of heavy metals in the fodder, the water and the mare milk depended on the. However, in the studies, the content of heavy metals in various farm objects did not exceed the maximum permissible concentrations.

Table 5: The average level of heavy metals in the water - soil - fodder - milk food chain at the base farms in the Almaty region

\begin{tabular}{|c|c|c|c|c|c|c|c|c|}
\hline \multirow[b]{3}{*}{ Heavy metals } & \multicolumn{8}{|c|}{ The content of the metals } \\
\hline & \multicolumn{2}{|c|}{ In the water, $\mathrm{mg} / \mathrm{dm}^{3}$} & \multicolumn{2}{|c|}{ In the grazing land, $\mathrm{mg} / \mathrm{kg}$} & \multicolumn{2}{|c|}{ In the fodder, $\mathrm{mg} / \mathrm{kg}$} & \multicolumn{2}{|c|}{ In the milk, mg/l } \\
\hline & Actual & MPC & Actual & MPC & Actual & MPC & Actual & MPC \\
\hline \multicolumn{9}{|c|}{ Aidarbayev peasant farm } \\
\hline $\mathrm{Cd}$ & 0.0005 & 0.001 & 0.1971 & 1.0 & 0.0332 & 0.3 & 0.0102 & 0.03 \\
\hline $\mathrm{Pb}$ & 0.0199 & 0.03 & 0.3083 & 3.2 & 0.5142 & 3.2 & 0.0089 & 0.1 \\
\hline As & 0 & 0.05 & 0.3483 & 2.0 & 0.0038 & 0.5 & 0 & 0.1 \\
\hline $\mathrm{Hg}$ & 0 & 0.0005 & 0.4806 & 2.1 & 0.0037 & 0.05 & 0 & 0.05 \\
\hline \multicolumn{9}{|c|}{ KazAgroStandard LLP } \\
\hline $\mathrm{Cd}$ & 0.0004 & 0.001 & 0.0450 & 1.0 & 0.0715 & 0.3 & 0.0097 & 0.03 \\
\hline $\mathrm{Pb}$ & 0.0165 & 0.03 & 0.1912 & 3.2 & 0.3371 & 3.2 & 0.0033 & 0.1 \\
\hline As & 0 & 0.05 & 0.2294 & 2.0 & 0.0809 & 0.5 & 0 & 0.1 \\
\hline $\mathrm{Hg}$ & 0 & 0.0005 & 0.2971 & 2.1 & 0.0104 & 0.05 & 0 & 0.05 \\
\hline
\end{tabular}




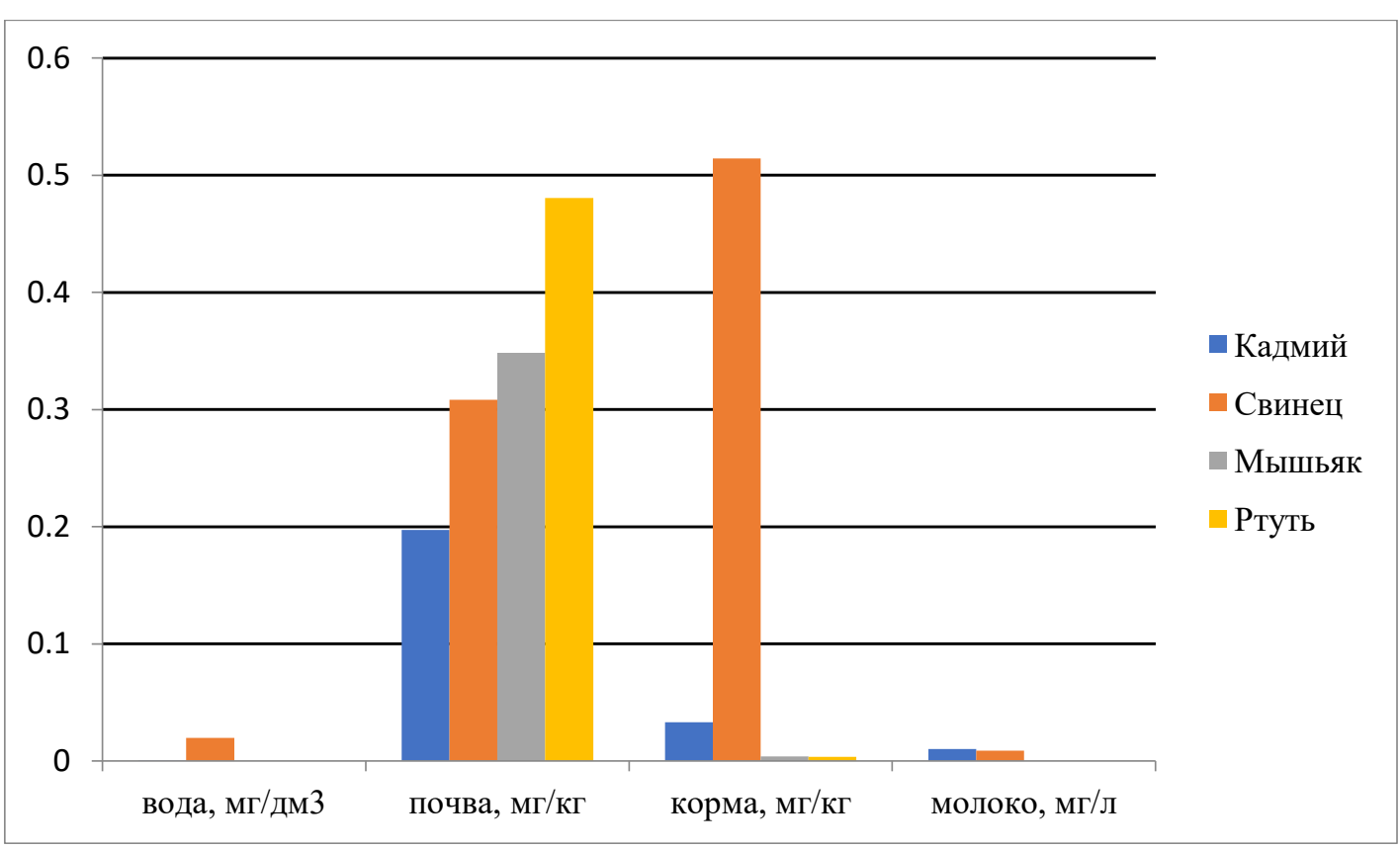

Fig. 1: The dynamics of heavy metals and toxic elements migration in the objects at the Aidarbayev peasant farm

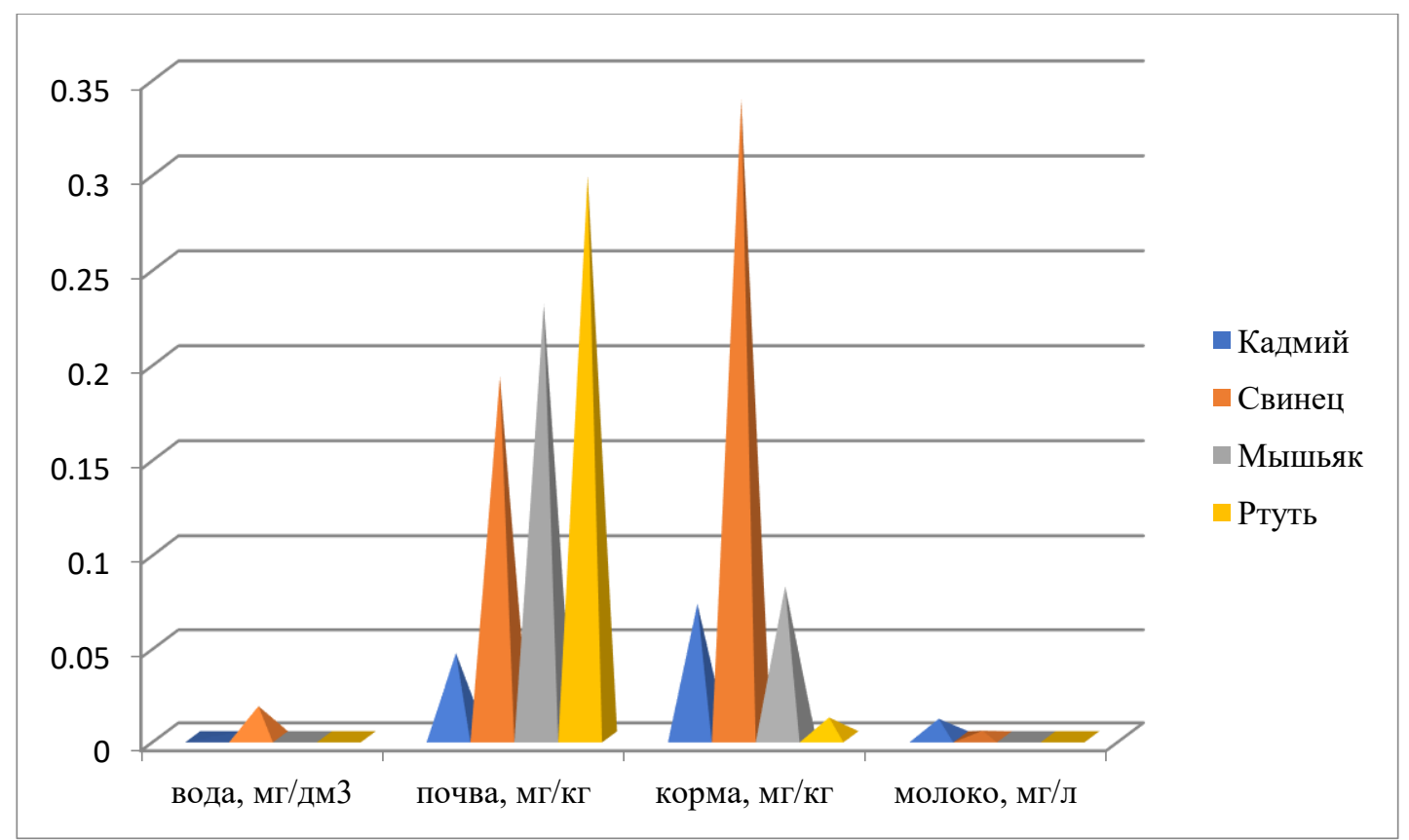

Fig. 2: The dynamics of heavy metals and toxic elements migration in the objects at KazAgroStandard LLP

It was noted that the highest content of ecotoxicants was observed in the green grass mass, which formed the basis for the diet in the grazing period. Studying the milk for the presence of heavy metals showed that this type of product met the sanitary and hygienic requirements.

Given the possible likelihood of heavy metals accumulation in the water, the soil and the cattle diets, studies in this area should become a prerequisite for assessing the environmental safety of the products in the districts of the Almaty region.

\section{Conclusion}

Considering the obtained data, the authors have found that in the studied administrative districts of the Almaty region, the calculated transition rates in the 
water - soil - fodder - milk system show that the greatest heavy metals transition rates have been noted for lead and cadmium and the least transition rates have been noted for mercury and arsenic.

Thus, the presented data show that obtaining environmentally friendly dairy raw materials is only possible with systematic monitoring of the environment at the farms, which should not be contaminated with toxic elements.

The comparative analysis of the actual content of toxic elements in the fodder and their maximum permissible levels has shown that at the base farms of the Almaty region, there are all the possibilities of obtaining ecologically safe products of animal breeding. In developing the environmentally substantiated technologies for milk production, the authors recommend using the established heavy metals transition rates in the soil - fodder - milk chain.

\section{Acknowledgment}

The authors are grateful to the base farms in the Almaty region and the Kazakh National Agrarian University for providing the conditions for scientific research and funding.

\section{Funding Information}

The research has been performed based on the scientific project AR05135439 "Veterinary and sanitary control and monitoring assessment of the migration of heavy metals in the water-soil-fodder-products food chain for 2018-2020.

\section{Author's Contributions}

All authors equally contributed in this work.

\section{Ethics}

The corresponding author confirms that all other authors have read and approved the manuscript and no ethical issues have been involved.

\section{References}

Abdulkhaliq, A., Swaileh, K., Hussein, R. M., \& Matani, M. (2012). Levels of metals ( $\mathrm{Cd}, \mathrm{Pb}, \mathrm{Cu}$ and $\mathrm{Fe}$ ) in cow's milk, dairy products and hen's eggs from the West Bank, Palestine. International Food Research Journal, 19(3), 1089-1094.

https://fada.birzeit.edu/bitstream/20.500.11889/3223 13/23\%20Metals-Dairy\%20(2012).pdf

Ahlam, A. E., Amer, A. A., Abo El-Makarem, H. S., \& Al Hend, H. A. H. (2017). Heavy Metals Residues in Some Dairy Products. Alexandria Journal of Veterinary Sciences, 52(1), 334-346. https://doi.org/10.5455/ajvs.230723
Caggiano, R., Sabia, S., D’Emilio, M., Macchiato, M., Anastasio, A., Ragosta, M., \& Paino, S. (2005). Metal levels in fodder, milk, dairy products and tissues sampled in ovine farms of Southern Italy. Environmental Research, 99(1), 48-57. https://doi.org/10.1016/j.envres.2004.11.002

Chary, N. S., Kamala, C. T., \& Raj, D. S. S. (2008). Assessing risk of heavy metals from consuming food grown on sewage irrigated soils and food chain transfer. Ecotoxicology and Environmental Safety, 69(3), 513-524. https://doi.org/10.1016/j.ecoenv.2007.04.013

Fomina, S. F., \& Stepanova, N. V. (2015). Analiz soderzhaniya khimicheskikh kontaminantov $\mathrm{V}$ produktakh pitaniya Respubliki Tatarstan [Analysis of the content of chemical contaminants in the food products in the Republic of Tatarstan]. Modern Issues of Science and Education, 6, 241. https://www.science-education.ru/pdf/2015/6/477.pdf

Gabryszuk, M., Sloniewski, K., Metera, E., \& Sakowski, T. (2010). Content of mineral elements in milk and hair of cows from organic farms. Journal of Elementology, 15(2), 259-267. https://doi.org/10.5601/jelem.2010.15.2.259-267

Gholizadeh, A., Borůvka, L., Saberioon, M. M., Kozak, J., Vašát, R., \& Němeček, K. (2015). Comparing different data preprocessing methods for monitoring soil heavy metals based on soil spectral features. Soil and Water Research, 10(4), 218-227. https://doi.org/10.17221/113\%2F2015-SWR

Gosstandart of Russia. (1995). GOST 26929-94. Raw materials and food products. Sample preparation. Mineralization to determine the content of toxic elements. IPK Izdatel'stvo standartov, Moscow. https://standartgost.ru/g/\%D0\%93\%D0\%9E\%D0\% A1\%D0\%A2_26929-94

Gosstandart of Russia. (2001). GOST 30692-2000. Fodders, mixed fodders, mixed fodder raw materials. Atomic absorption method for determining the content of copper, lead, zinc and cadmium. IPK Izdatel'stvo standartov, Moscow. https://standartgost.ru/g/\%D0\%93\%D0\%9E\%D0\% A1\%D0\%A2_30692-2000

Gosstandart of Russia. (2002). GOST R ISO 5725-6-2002. Accuracy (correctness and precision) of measurement methods and results. Standartinform, Moscow. https://www.standards.ru/document/4134794.aspx

Gosstandart of the USSR. (1989). GOST 28168-89. Soils. Sample selection. Standartinform, Moscow. https://www.standards.ru/document/4150976.aspx

Grigorieva, A. A., \& Mironova, G. E. (2018). Akkumulyatsiya tyazhelykh metallov $\mathrm{v}$ pochve $\mathrm{i} \mathrm{v}$ kormovykh travakh Tsentralnoi Yakutii [Accumulation of heavy metals in the soil and fodder herbs in Central Yakutia]. Bulletin of NEFU, 1(63), 5-12. https://cyberleninka.ru/article/n/akkumulyatsiyatyazhelyh-metallov-v-pochve-i-v-kormovyh-travahtsentralnoy-yakutii 
Hapke, H. J. (1996). Heavy metal transfer in the food chain to humans. In: Rodriguez-Barrueco C. (eds) Fertilizers and Environment. Developments in Plant and Soil Sciences, (pp. 431-436), Springer, Dordrecht. https://doi.org/10.1007/978-94-009-1586-2_73

Kazhmukhanbetkizi, Z. A., Eleubaevich, N. B., \& Maksutovna, B. S. (2019). The content of heavy metals in the grass, in water and milk of Mares according to the season of the year. Ukrainian Journal of Ecology, 9(1), 86-88. https://cyberleninka.ru/article/n/the-contentof-heavy-metals-in-the-grass-in-water-and-milk-ofmares-according-to-the-season-of-the-year

Lante, A., Lomolino, G., Cagnin, M., \& Spettoli, P. (2006). Content and characterisation of minerals in milk and in Crescenza and Squacquerone Italian fresh cheeses by ICP-OES. Food Control, 17(3), 229-233. https://doi.org/10.1016/j.foodcont.2004.10.010

M-MVI-80-2008. (2008). Methods for measuring the mass fraction of elements in samples of soils, grounds and bottom sediments by atomic emission and atomic absorption spectrometry. Limited Liability Company "Monitoring", St. Setersburg. https://www.russiangost.com/p-154902-m-mvi-802008.aspx

Mansour, S. A. (2014). Monitoring and health risk assessment of heavy metal contamination in food. In: Bhat R., \& Gomez-Lopez, V. M. (Eds.), Practical Food Safety: Contemporary Issues and Future Directions, (pp. 235-255), John Wiley and Sons Limited, ISBN: 9781118474600, ISBN: 9781118474563.

Nanda, S., \& Abraham, J. (2013). Remediation of heavy metal contaminated soil. African Journal of Biotechnology, 12(21), 3099-3109. https://www.ajol.info/index.php/ajb/article/view/1 31630

Rai, P. K., Lee, S. S., Zhang, M., Tsang, Y. F., \& Kim, K. H. (2019). Heavy metals in food crops: Health risks, fate, mechanisms and management. Environment International, $\quad 125$, 365-385. https://doi.org/10.1016/j.envint.2019.01.067

Rosstandart. (2012). GOST 31862-2012. Drinking water. Sample selection. Standartinform, Moscow. https://www.standards.ru/document/5304006.aspx

Rosstandart. (2014). GOST 26809.1-2014. Milk and dairy products. Acceptance rules, sampling methods and preparation of samples for analysis. Standartinform, Moscow. https://www.standards.ru/document/5531884.aspx

Rosstandart. (2016). GOST ISO 6497-2014. Fodders. Sample selection. Standartinform, Moscow.https://www.standards.ru/document/61407 01.aspx

Salah, F. A. A. E., Esmat, I. A., \& Mohamed, A. B. (2013). Heavy metals residues and trace elements in milk powder marketed in Dakahlia Governorate. International Food Research Journal, 20(4), 1807-1812.
Sarsembayeva, N., Kirkimbayeva, Z., Urkimbayeva, A., Biltebay, A., Abdigaliyeva, T., \& Valiyeva, Z. (2018). Study of the degree of heavy and toxic metal pollution of soils and forages of peasant farms in the Almaty region. International Journal of Mechanical Engineering and Technology, 9(10), 753-760.

Sarsembayeva, N. B., Abdigaliyeva, T. B., Biltebay, A. N., Zhumagulova, S. Z. H., \& Aidarbekova, A. B. (2019). Analiz soderzhaniya tyazhelykh i toksichnykh metallov $\mathrm{v}$ moloke korov bazovykh khozyaistv Almatinskoi oblasti [Analysis of the content of heavy and toxic metals in the cow milk from the base farms in the Almaty region]. Postgraduate and Applicant, 1, 86-90.

Sarsembayeva, N.B., T.B. Abdigaliyeva, Z.A. Utepova, A.N. Biltebay, S.Z. Zhumagulova. 2020. Heavy metal levels in milk and fermented milk products produced in the Almaty region, Kazakhstan. Veterinary World, 13(4): 609-613. https://doi.org/10.14202/vetworld.2020.609-613

Shahbazi, Y., F. Ahmadi and F. Fakhari. 2016. Voltammetric determination of $\mathrm{Pb}, \mathrm{Cd}, \mathrm{Zn}, \mathrm{Cu}$ and Se in milk and dairy products collected from Iran: An emphasis on permissible limits and risk assessment of exposure to heavy metals. Food Chemistry, 192: 1060-1067. https://doi.org/10.1016/j.foodchem.2015.07.123

Sherene, T. 2010. Mobility and transport of heavy metals in polluted soil environment. Biological Forum An International Journal, 2 (2): 112-121.

Skalny, A. V., \& Bykov, A. T. (2003). Ekologofiziologicheskii aspekt primeneniya makro- $\mathrm{i}$ mikroelementov $\mathrm{v}$ vosstanovitelnoi meditsine [The ecological and physiological aspects of using macroand microelements in rehabilitation medicine]. Editorial and Publishing House of SEI OSU, Orenburg.

Szyczewski, P., Siepak, J., Niedzielski, P., \& Sobczyński, T. (2009). Research on heavy metals in Poland. Pol Journal Environmental Stud, 18(5), 755-768.

Tripathi, R. M., Raghunath, R., Sastry, V. N., \& Krishnamoorthy, T. M. (1999). Daily intake of heavy metals by infants through milk and milk products. Science of the Total Environment, 227(2-3), 229-235. https://doi.org/10.1016/s0048-9697(99)00018-2

Verotchenko, M. A. (2014). Ekologicheskaya otsenka moloka na soderzhanie $\mathrm{v}$ nem tyazhelykh metallov $\mathrm{v}$ sootvetstvii $\mathrm{s}$ trebovaniyami tekhnicheskogo reglamenta Tamozhennogo Soyuza [Environmental milk assessment for the content of heavy metals following the requirements of the Customs Union Technical Regulations]. Zootechny, 7, 20-21. https://www.elibrary.ru/item.asp?id=21630201

White, P. M., Wolf, D. C., Thoma, G. J., \& Reynolds, C. M. (2006). Phytoremediation of alkylated polycyclic aromatic hydrocarbons in a crude oil-contaminated soil. Water, Air and Soil Pollution, 169(1), 207-220. https://doi.org/10.1007/s11270-006-2194-0 